\title{
Designer ligands. Part 14. Novel Mn(II), Ni(II) and Zn(II) complexes of benzamide- and biphenyl-derived ligands
}

\author{
Kevin W. Wellington, ${ }^{\mathrm{b}}$ Perry T. Kaye, ${ }^{\mathrm{a} *}$ and Gareth M. Watkins ${ }^{\mathrm{a}}$ \\ ${ }^{a}$ Department of Chemistry, Rhodes University, Grahamstown, 6140, South Africa \\ ${ }^{b}$ CSIR Biosciences, Pinelands, Ardeer Road, Modderfontein, 1645, South Africa \\ E-mail: P.Kaye@ru.ac.za
}

\begin{abstract}
Manganese(II), nickel(II) and zinc(II) complexes have been prepared using various benzamideand biphenyl-derived ligands; their structures have been investigated using infrared spectroscopy and it is apparent that, depending on the ligand, the metal centres adopt octahedral, tetrahedral and distorted tetrahedral coordination geometries. The catecholase activity of the manganese(II) complexes has also been evaluated.
\end{abstract}

Keywords: Manganese(II), nickel(II) and zinc(II) complexes, biomimetic ligands, catalysis

\section{Introduction}

Metals play important roles in biological systems and, in earlier papers, we have described the development of biomimetic complexes designed to mimic the active site of tyrosinase, ${ }^{1}$ an enzyme capable of ortho-hydroxylating phenols (phenolase activity) and oxidising catechols to ortho-quinones (catecholase activity)., ${ }^{2,3}$ Copper $^{4}$ and cobalt ${ }^{5}$ complexes of novel ligands, prepared in our laboratory, have also been shown to exhibit catecholase activity, and our interests broadened to include other transition metal systems, viz., manganese(II), nickel(II) and zinc(II) complexes. Manganese metalloenzymes containing dinuclear active sites ${ }^{6}$ have been found to exhibit catalytic activity, while zinc(II) is often present in the active site of hydrolytic metalloenzymes. ${ }^{7-10}$ Nickel also plays important roles in biological systems. The first such system to be discovered, the enzyme urease, was isolated from jack beans ${ }^{11-12}$ and shown by UVvisible spectroscopy and EXAFS studies to contain two octahedral nickel(II) ions in a nitrogenand oxygen-donor environment. Nickel has subsequently been found in other enzymes, viz., hydrogenases, $\mathrm{CO}$ dehydrogenases and coenzyme $\mathrm{F}_{430} .{ }^{12}$ It has been found that the hydrogenases and $\mathrm{CO}$ dehydrogenases have nickel(III) (low spin $d^{7}$ ) and Fe-S clusters present in their structures ${ }^{12}$ while nickel(II) in coenzyme $\mathrm{F}_{430}$, a cofactor of methyl coenzyme $\mathrm{M}$ reductase, exhibits square planar geometry. 
We have previously reported the preparation of ligands, which are capable of chelating two metal ions and, in which, the coordinating moieties are separated by biphenyl, ${ }^{13} 1,10$ phenanthroline $^{14}$ or acyclic spacers. ${ }^{15}$ In this paper, we now discuss: - the synthesis of the selected benzamide derivatives 1a-c; the capacity of such compounds and of various biphenyl derivatives to serve as multidentate ligands for the preparation of novel $\mathrm{Mn}$ (II), $\mathrm{Ni}$ (II) and $\mathrm{Zn}$ (II) complexes; and the biomimetic catecholase activity of the $\mathrm{Mn}(\mathrm{II})$ complexes.

\section{Results and Discussion}

The ligands 1a-c (Scheme 1) were prepared by treating benzoic acid with carbonyl diimidazole $(\mathrm{CDI})^{13}$ in dimethylformamide (DMF), followed by the respective primary amines, histamine, 2(2-aminoethyl)benzimidazole and 2-(2-aminoethyl)pyridine. [Histamine had to be released from its dihydrochloride salt by treatment with sodium methoxide, while 2-(2aminoethyl)benzimidazole was prepared from 1,2-diaminobenzene and $\beta$-alanine. $\left.{ }^{16}\right]$ The synthesis of the biphenyl-derived ligand 2 , which also contains imidazolyl groups, has been reported previously. ${ }^{13}$ Schemes 2-5 outline the use of these ligands in the formation of manganese(II), nickel(II) and zinc(II) complexes, the structural assignments of which are based on a consideration of the microanalysis and infrared data.
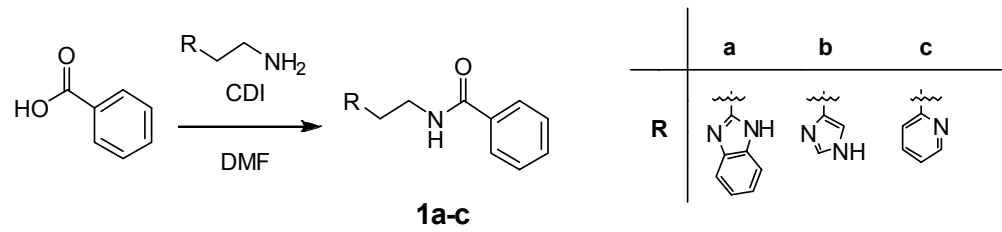

Scheme 1. Synthesis of benzamide-derived ligands. 


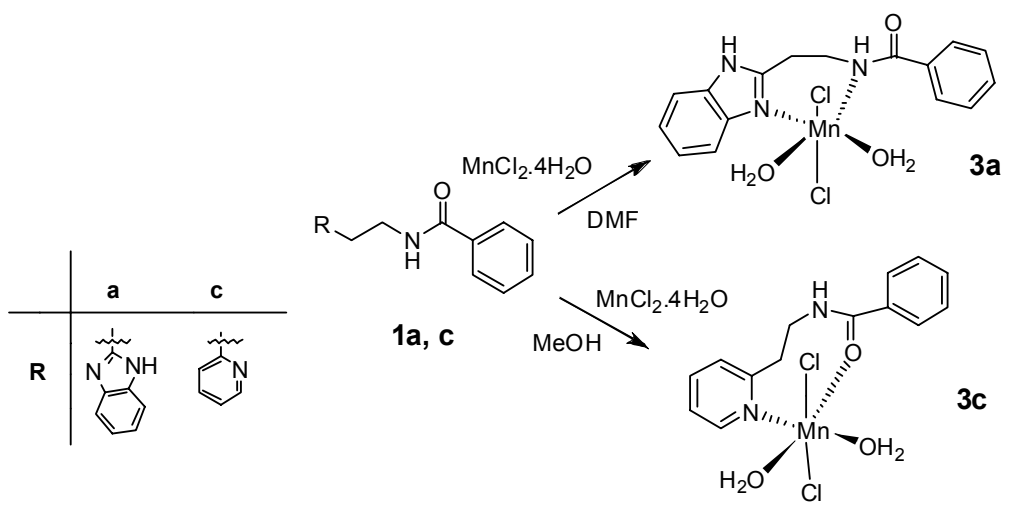<smiles>O=C(NCCc1c[nH]cn1)c1ccccc1-c1ccccc1C(=O)NCCc1c[nH]cn1</smiles><smiles>O=C(NCCOCn1cncc1CCNC(=O)n1cncc1Cl)c1ccccc1-c1ccccc1Cl</smiles>

Scheme 2. Manganese(II) complexes of the benzamide- and biphenyl-derived ligands.

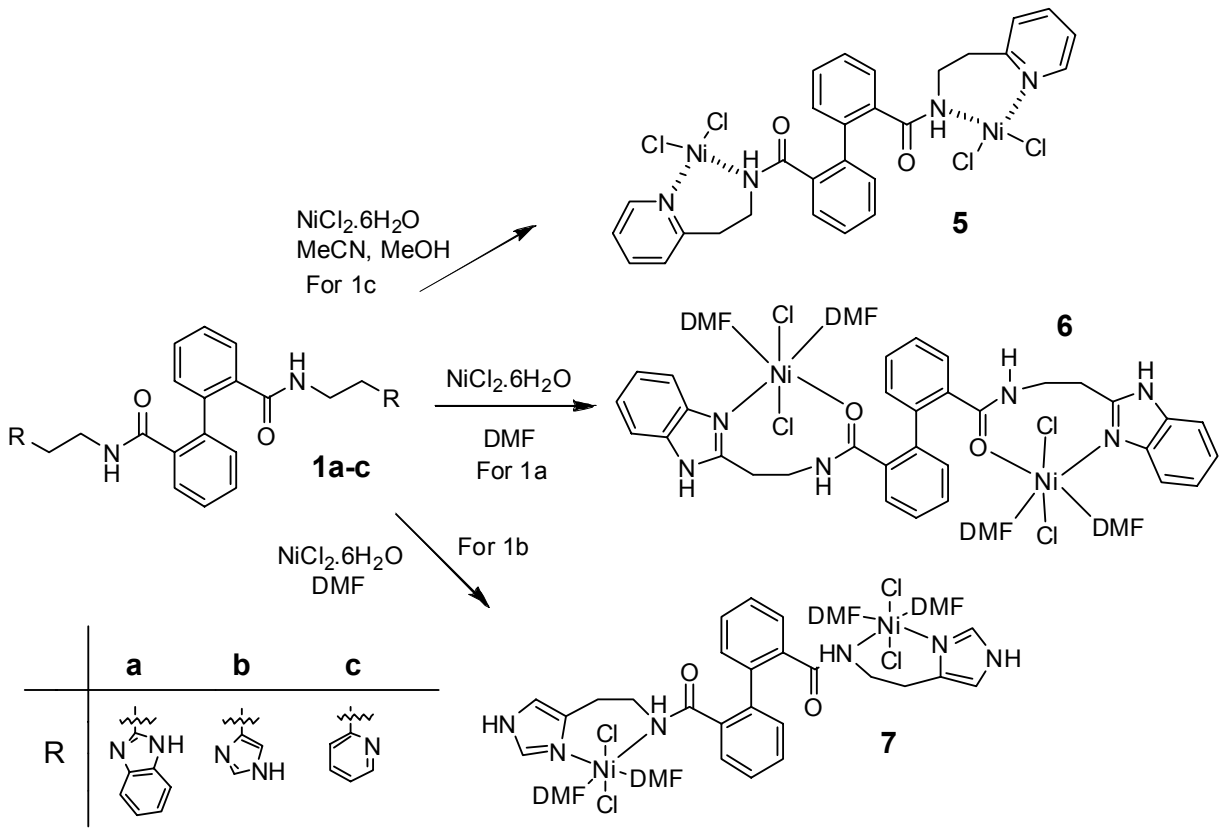

Scheme 3. Nickel(II) complexes of the biphenyl-derived ligands. 


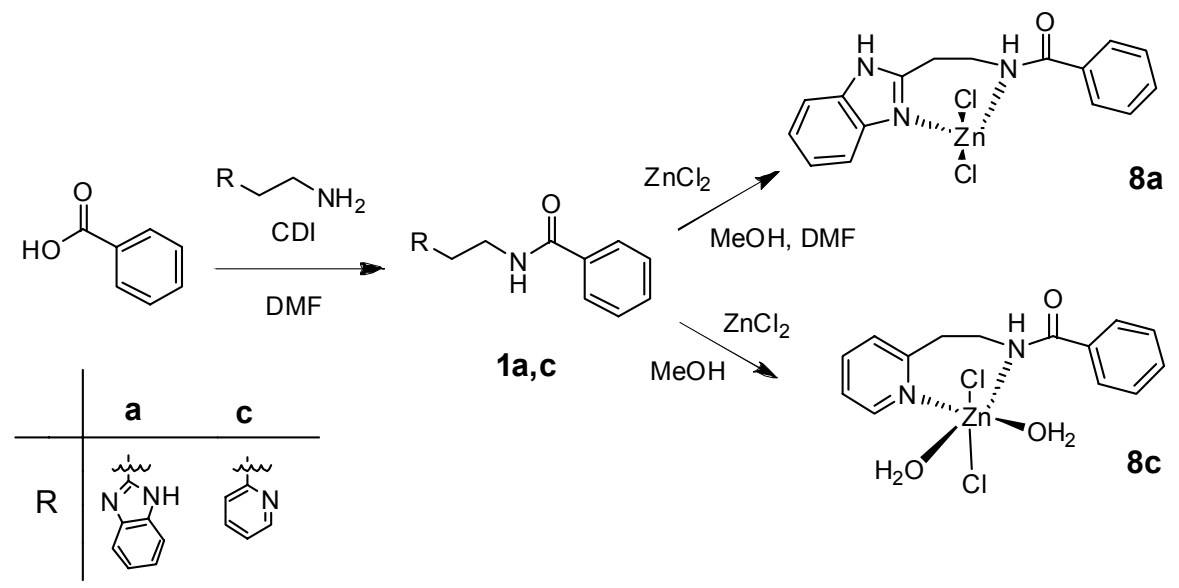

Scheme 4. Zinc(II) complexes of the benzamide-derived ligands.

Microanalysis data for the various complexes are summarized in Table 1. It is apparent that the manganese complexes $\mathbf{3 a}$ and $\mathbf{3 c}$ are mononuclear while complex $\mathbf{4}$ is dinuclear; all three complexes, however, contain two chloride ions (Scheme 2). The nickel complexes 5-7 (Scheme 3) all appear to be dinuclear and each complex contains four chloride ions. The diamide- and monoamide zinc complexes [8a,c and 9a-c, respectively (Schemes 4 and 5)] all appear to be mononuclear and contain only two chloride ions. The structures proposed for the various complexes (Schemes 2-5) are consistent with the microanalysis and corresponding infrared data (Table 2).

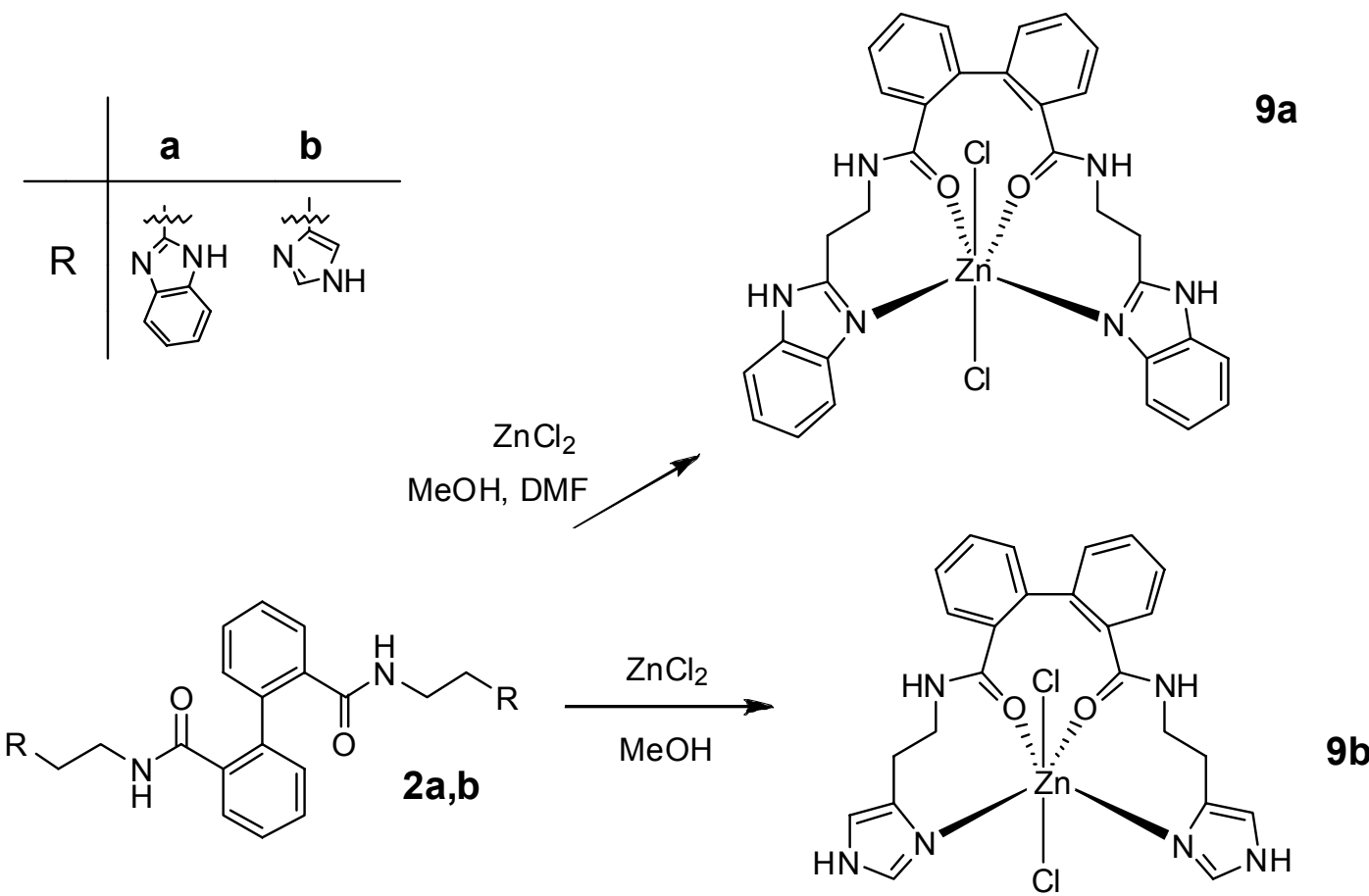

Scheme 5. Zinc(II) complexes of the biphenyl-derived ligands. 
Table 1. Microanalytical data for the metal complexes followed, in parentheses, by the calculated values

\begin{tabular}{ccccc}
\hline Complex & $\begin{array}{c}\text { Complex } \\
\text { Stoichiometry }\end{array}$ & \% Carbon & \% Hydrogen & \% Nitrogen \\
\hline $\mathbf{3 a}$ & $\mathrm{Mn}(\mathbf{1 a}) \mathrm{Cl}_{2} \cdot 2 \mathrm{H}_{2} \mathrm{O}$ & $44.7(45.0)$ & $4.5(4.5)$ & $9.6(9.8)$ \\
$\mathbf{3 c}$ & $\mathrm{Mn}(\mathbf{1 c}) \mathrm{Cl}_{2} \cdot 2 \frac{1}{2} \mathrm{H}_{2} \mathrm{O}$ & $42.6(42.3)$ & $4.2(4.3)$ & $7.1(7.1)$ \\
$\mathbf{4}$ & $\mathrm{Mn}_{2}(\mathbf{2}) \mathrm{Cl}_{2}$ & $47.8(47.5)$ & $3.5(3.7)$ & $13.5(13.8)$ \\
$\mathbf{5}$ & $\mathrm{Ni}_{2}(\mathbf{1 c}) \mathrm{Cl}_{4} \cdot 6 \mathrm{H}_{2} \mathrm{O}$ & $40.5(41.1)$ & $4.2(4.7)$ & $7.0(6.9)$ \\
$\mathbf{6}$ & $\mathrm{Ni}_{2}(\mathbf{1 a}) \mathrm{Cl}_{2} \cdot(\mathrm{DMF})_{4}$ & $39.4(38.9)$ & $3.3(3.8)$ & $9.5(9.1)$ \\
$\mathbf{7}$ & $\mathrm{Ni}_{2}(\mathbf{1 b}) \mathrm{Cl}_{2} \cdot(\mathrm{DMF})_{4} \cdot 3 \mathrm{H}_{2} \mathrm{O}$ & $41.4(41.8)$ & $5.2(5.7)$ & $13.2(13.5)$ \\
$\mathbf{1 1}$ & $\mathrm{Ni}(\mathbf{1 0}) \mathrm{Cl}_{2} \cdot 1 \mathrm{H}_{2} \mathrm{O}$ & $57.1(56.5)$ & $4.6(5.0)$ & $6.7(6.3)$ \\
$\mathbf{8 a}$ & $\mathrm{Zn}(\mathbf{1 a}) \mathrm{Cl}_{2} \cdot \mathrm{DMF}_{2}$ & $48.3(48.1)$ & $4.6(4.7)$ & $11.4(11.8)$ \\
$\mathbf{8 c}$ & $\mathrm{Zn}(\mathbf{1 c}) \mathrm{Cl}_{2} \cdot 3 \mathrm{H}_{2} \mathrm{O}$ & $40.4(40.5)$ & $4.3(4.6)$ & $6.8(6.7)$ \\
$\mathbf{9 a}$ & $\mathrm{Zn}(\mathbf{2 a}) \mathrm{Cl}_{2} \cdot 3 \mathrm{H}_{2} \mathrm{O}$ & $51.2(50.9)$ & $4.9(4.6)$ & $11.4(11.1)$ \\
$\mathbf{9 b}$ & $\mathrm{Zn}(\mathbf{2 b}) \mathrm{Cl}_{2} \cdot 2 \mathrm{H}_{2} \mathrm{O}$ & $47.9(48.0)$ & $4.7(4.7)$ & $13.8(14.0)$ \\
\hline
\end{tabular}

${ }^{\text {a }}$ Presence of $\mathrm{H}_{2} \mathrm{O}$ and/or DMF supported by IR data; see Table 2 for $v\left(\mathrm{OH}_{2}\right)$ data.

Mid-IR spectra of the complexes were used to establish whether the manganese ions coordinate through the amide nitrogen or oxygen atoms, while the environment of the coordinated chloride anions was determined by running spectra in the far-IR region. Both negative and positive shifts may be observed for the amide carbonyl band (amide I) - a negative shift indicating coordination via the amide oxygen, a positive shift coordination via the amide nitrogen. For the manganese monoamide complex 3a, the absence of any significant change in $v_{\mathrm{C}=\mathrm{O}}$ coupled with a small positive shift $\left(16 \mathrm{~cm}^{-1}\right)$ of the benzamide $\mathrm{NH}$ band (relative to the free ligand) indicates coordination via the amide nitrogen, while the presence of the benzimidazole $\mathrm{NH}$ indicates coordination with the tertiary benzimidazole nitrogen. In the case of the pyridyl analogue 3c and the diamide complex 4 , the significant positive amide $\mathrm{NH}$ band shifts, coupled with the negative $\mathrm{C}=\mathrm{O}$ band shifts, are consistent with coordination via the amide carbonyl oxygen. The far-IR bands at 278 and $276 \mathrm{~cm}^{-1}$ are consistent with chloride ions in an octahedral environment in complexes 3a and 3c, respectively; the two, lower-frequency bands at 217 and $271 \mathrm{~cm}^{-1}$ for complex 4 are characteristic of chloride bridging. ${ }^{17}$

Coordination of nickel through the amide oxygen in the diamide complex $\mathbf{6}$ is indicated by the small positive $\mathrm{NH}$ and negative $\mathrm{C}=\mathrm{O}$ shifts. In complexes 5 and 7, coordination through the amide nitrogen is suggested by the positive amide NH shifts; complex 7 also exhibits a positive carbonyl shift, but complex 5 none. The presence of the amide NH band in all cases implies that deprotonation of the amide nitrogen has not occurred - an observation consistent with the microanalysis data for these nickel complexes. Very weak bands at 276 and $325 \mathrm{~cm}^{-1}$ in the far IR region were observed for complex 5 and are attributed to $\mathrm{Ni}-\mathrm{Cl}$ stretches in a square planar environment. In the case of complexes 6 and 7 the strong bands in the 370-390 $\mathrm{cm}^{-1}$ region are 
attributed to chloride anions coordinated in a trans octahedral geometry. ${ }^{17}$ The X-ray crystal structure for complex 11 (Scheme 6 and Figure 1) clearly confirms the tetrahedral geometry responsible for the two relatively strong bands at 289 and $329 \mathrm{~cm}^{-1}$; these values are characteristic of chloride ions coordinated in a tetrahedral environment ${ }^{17}-$ in contrast with the somewhat lower values attributed to the square-planar complex $\mathbf{5}$.

Table 2. Summary of the IR frequencies $\left(V_{\mathrm{M}-\mathrm{Cl}}\right)$ and the amide frequency shifts $\left(\Delta V_{\mathrm{NH}}\right.$ and $\left.\Delta V_{\mathrm{C}=\mathrm{O}}\right)$ on formation of the metal complexes

\begin{tabular}{ccccc}
\hline Complex & $\boldsymbol{\Delta} \boldsymbol{v}_{\mathbf{N} \mathbf{H}} / \mathbf{c m}^{-\mathbf{1}}$ & $\boldsymbol{\Delta} \boldsymbol{v}_{\mathbf{C}=\mathbf{0}} / \mathbf{c m}^{-\mathbf{1}}$ & $\boldsymbol{v}_{\mathbf{M}-\mathbf{C} /} / \mathbf{c m}^{-\mathbf{1}}$ & $\boldsymbol{v}_{\mathbf{O H}}{ }^{\mathrm{a}} / \mathbf{c m}^{-\mathbf{1}}$ \\
\hline $\mathbf{3 a}$ & 16 & 1 & 278 & 3500 \\
$\mathbf{3 c}$ & 54 & -4 & 276 & 3400 \\
$\mathbf{4}$ & 42 & -21 & 217,271 & - \\
$\mathbf{5}$ & $15^{\mathrm{b}}$ & $0^{\mathrm{b}}$ & 276,325 & $3375^{\mathrm{b}}$ \\
$\mathbf{6}$ & 11 & -6 & 387 & 3321 \\
$\mathbf{7}$ & 49 & 13 & 378 & 3400 \\
$\mathbf{8 a}$ & 16 & 31 & 287 & - \\
$\mathbf{8 c}$ & $101^{\mathrm{c}, \mathrm{d}}$ & $0^{\mathrm{c}}$ & 278 & $3496^{\mathrm{c}}$ \\
$\mathbf{9 a}$ & 50 & -8 & 278 & $3420(\mathrm{sh})$ \\
$\mathbf{9 b}$ & 83 & 10 & 281 & $3520(\mathrm{sh})$ \\
\hline
\end{tabular}

${ }^{\mathrm{a}}$ Broad $\mathrm{H}_{2} \mathrm{O}$ bands. ${ }^{\mathrm{b}}$ In $\mathrm{HCBD} .{ }^{\mathrm{c}}$ In NaCl. ${ }^{\mathrm{d}}$ Shoulder.

For complex 8a, the small positive shifts of both the amide carbonyl and amide $\mathrm{NH}$ bands indicate coordination through the amide nitrogen (the apparent broadening of the amide carbonyl band is attributed to the presence of DMF). In complex 8c, no shift of the amide carbonyl band is evident and the large positive shift $\left(\mathrm{ca} .100 \mathrm{~cm}^{-1}\right)$ of the amide $\mathrm{NH}$ band points to coordination with the amide nitrogen. The negative shift of the amide $\mathrm{CO}$ band in complexes $9 \mathbf{a}$ and $\mathbf{9 b}$ is an indication that coordination occurs with the amide oxygen atom. From the data in Table 2 it appears that the amide functionality in these complexes is resistant to deprotonation. Two $\mathrm{Zn}-\mathrm{Cl}$ bands characteristic of tetrahedral geometry are anticipated in the far-lR region (ca. 295 and 327 $\mathrm{cm}^{-1}$ ) for complex 8a, but this was not observed. ${ }^{17}$ Instead, a very strong, broad band, with shoulders, is observed at $c a .287 \mathrm{~cm}^{-1}$. This band may reflect accidental degeneracy of the symmetric and anti-symmetric $\mathrm{Zn}-\mathrm{Cl}$ stretches due to a distorted tetrahedral zinc arrangement within this complex. The mononuclear zinc complexes 9a and 9b exhibit less intense bands at lower wave-numbers in the far-IR region and these are attributed to $\mathrm{Zn}-\mathrm{Cl}$ stretches in an octahedral arrangement. ${ }^{17}$ 


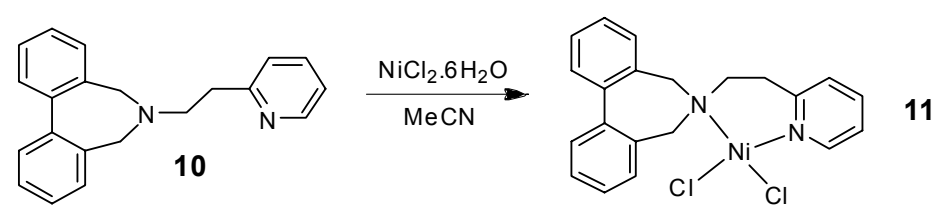

\section{Scheme 6}

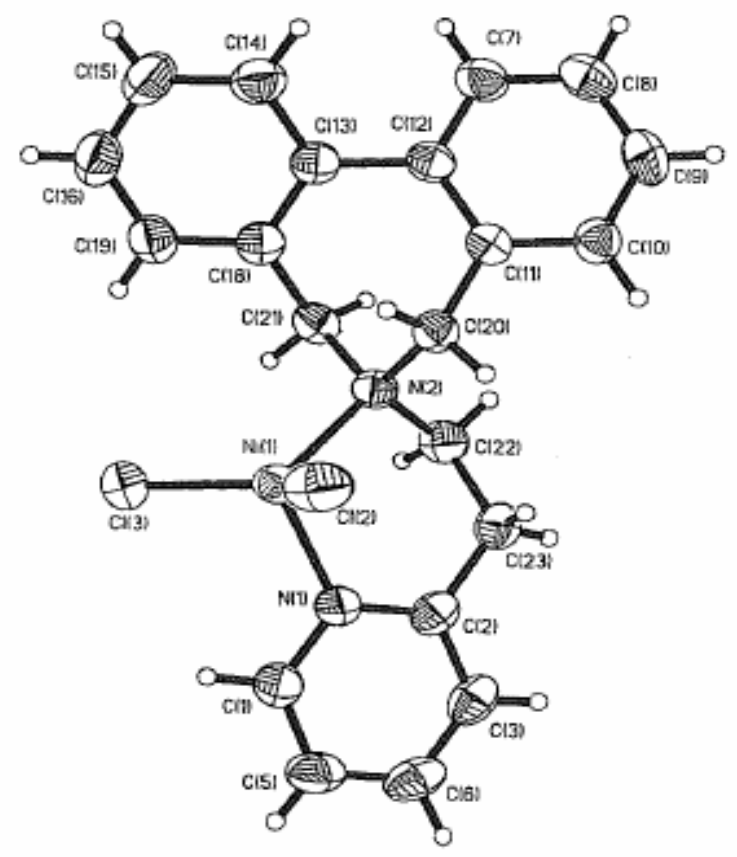

Figure 1. X-ray crystal structure of complex 11 showing the crystallographic numbering.

NMR analysis $\left({ }^{1} \mathrm{H},{ }^{13} \mathrm{C}\right.$ and DEPT 135) of the zinc(II) complexes revealed broadening of the ligand signals - a phenomenon observed in other studies ${ }^{18}$ and attributed to site-exchange processes involving coordination to the metal centre. Signal broadening is particularly marked in the ${ }^{1} \mathrm{H}$ NMR spectrum of complex $9 \mathbf{b}$, while the corresponding ${ }^{13} \mathrm{C}$ spectrum reveals doubling of certain ligand signals, consistent with slow (on the NMR time-scale) site-exchange between nonequivalent structural arrangements. In the case of complex $\mathbf{8 c}$, on the other hand, only slight broadening of the ${ }^{1} \mathrm{H}$ signals is apparent.

The phenolase and catecholase activity of the manganese(II) complexes were investigated to determine whether these complexes are capable of mimicking the active site of the enzyme tyrosinase. This was investigated because manganese is a redox metal and capable of binding oxygen - as can be seen in the formation of the complexes 3c and 4. In order to evaluate the 'phenolase' and 'catecholase' activity of the complexes, 3,5-di-t-butylphenol (3,5-DTBP) and 3,5 -di-t-butylcatechol $\left(3,5\right.$-DTBC) were used as the respective substrates. ${ }^{19-21}$ [3,5-DTBP is 
oxidized to 3,5-DTBC, which is oxidized, in turn, to 3,5-di-t-butyl-o-quinone (3,5-DTBQ); if formed, the oxidation products may be readily detected by ${ }^{1} \mathrm{H}-\mathrm{NMR}$ analysis].

Table 3. Catecholase activity of the manganese(II) complexes

\begin{tabular}{ccccccc}
\hline Complex & Solvent & $\begin{array}{c}\text { Reaction } \\
\text { Time/h }\end{array}$ & $\begin{array}{c}\text { Phenolase } \\
\text { Activity } \\
\text { Product }\end{array}$ & $\begin{array}{c}\text { Catecholase } \\
\text { Activity } \\
\text { Product }\end{array}$ & $\begin{array}{c}\text { \% } \\
\text { Conversion } \\
\text { within 24 h }\end{array}$ & $\begin{array}{c}\text { Recyclability: } \\
\text { \% coversion } \\
\text { within 24 h }\end{array}$ \\
\hline 3a & DMF & 24 & - & $o$-quinone & 100 & 100 \\
$\mathbf{3 c}$ & DMF & 24 & - & $o-q u i n o n e$ & 75 & - \\
$\mathbf{4}$ & DMF & 24 & - & $o$-quinone & 100 & 100 \\
\hline
\end{tabular}

It can be seen from the data summarised in Table 3 that while no phenolase activity was observed, catecholase activity was exhibited by the three manganese complexes 3a, 3c and $\mathbf{4}$. Phenolase activity requires initial axial binding of the phenol to the metal centre, followed by Berry pseudorotation of the trigonal bipyramidal complex, to expose the equatorial substrate to ortho-hydroxylation. This may be inhibited in these complexes and, as a consequence, no phenolase activity was observed. Catecholase activity is easier to achieve since it only requires a transfer of electrons and it is observed for complexes $\mathbf{3 a}, \mathbf{3 c}$ and $\mathbf{4}$. The catecholase activities of the mangananese complexes complexes 3a and $\mathbf{4}$ are greater than those exhibited by our biphenyl dinuclear cobalt(II) complexes $(\leq 88 \%)^{5}$ and by our macrocyclic dinuclear copper(I) and copper(II) complexes (63\% and $83 \%$ conversion, respectively), but comparable with the activity of our macrocyclic dinuclear cobalt(II) complex (100\% conversion). ${ }^{22}$ The catalytic oxidation of 3,5-DTBC to 3,5-DTBQ by a series of mononuclear manganese complexes has been reported previously, ${ }^{23}$ and our results are similar to those observed for $\left.\left[\mathrm{M}^{\mathrm{II}}(\text { diclofenac })_{2} \mathrm{H}_{2} \mathrm{O}\right)\right]$ complexes $(\mathrm{M}=\mathrm{Mn}, \mathrm{Co}, \mathrm{Ni}, \mathrm{Cu})^{24}$

\section{Conclusions}

It is apparent that the benzamide- and biphenyl-derived ligands examined here form complexes with manganese(II), nickel(II) and zinc(II) and that, depending on the ligand, the metal centres in these complexes adopt octahedral, tetrahedral or distorted tetrahedral coordination geometries. The structures of the complexes have been assigned using elemental analysis data, mid- and farinfrared and, where appropriate, NMR spectroscopic data. Significant catecholase activity (75 $100 \%$ conversion within 24 hours) has been demonstrated for the manganese(II) complexes 3a, 3c and 4, while complexes 3a and $\mathbf{4}$ also exhibit encouraging recyclability (100\% conversion within 24 hours). 
Table 4. Atomic coordinates $\left(\mathrm{x} 10^{4}\right)$ for complex 11 and equivalent isotropic displacement parameters $\left(\AA^{2} \times 10^{3}\right) \mathrm{U}(\mathrm{eq})$ is defined as one third of the trace of the orthogonalized Uij tensor

\begin{tabular}{lrrrr} 
& $\mathrm{x}$ & $\mathrm{y}$ & $\mathrm{Z}$ & $\mathrm{U}(\mathrm{eq})$ \\
\hline $\mathrm{Ni}(1)$ & $2197(1)$ & $1086(1)$ & $2108(1)$ & $41(1)$ \\
$\mathrm{Cl}(1)$ & $3094(1)$ & $1985(1)$ & $3225(1)$ & $68(1)$ \\
$\mathrm{N}(1)$ & $4142(3)$ & $589(2)$ & $1657(2)$ & $39(1)$ \\
$\mathrm{C}(1)$ & $5243(4)$ & $1134(2)$ & $1417(3)$ & $46(1)$ \\
$\mathrm{Cl}(2)$ & $861(1)$ & $1315(1)$ & $718(1)$ & $56(1)$ \\
$\mathrm{C}(2)$ & $6558(4)$ & $879(3)$ & $991(3)$ & $51(1)$ \\
$\mathrm{N}(2)$ & $1270(3)$ & $46(2)$ & $2744(2)$ & $33(1)$ \\
$\mathrm{C}(3)$ & $6770(4)$ & $38(3)$ & $816(2)$ & $50(1)$ \\
$\mathrm{C}(4)$ & $5679(4)$ & $-526(2)$ & $1082(2)$ & $46(1)$ \\
$\mathrm{C}(5)$ & $4344(4)$ & $-239(2)$ & $1499(2)$ & $40(1)$ \\
$\mathrm{C}(6)$ & $3092(4)$ & $-831(2)$ & $1754(3)$ & $48(1)$ \\
$\mathrm{C}(7)$ & $2390(4)$ & $-671(2)$ & $2734(2)$ & $42(1)$ \\
$\mathrm{C}(8)$ & $-192(3)$ & $-185(2)$ & $2207(2)$ & $35(1)$ \\
$\mathrm{C}(9)$ & $-1226(3)$ & $-791(2)$ & $2711(2)$ & $34(1)$ \\
$\mathrm{C}(10)$ & $-1432(4)$ & $-1611(2)$ & $2366(2)$ & $42(1)$ \\
$\mathrm{C}(11)$ & $-2527(4)$ & $-2130(2)$ & $2755(3)$ & $51(1)$ \\
$\mathrm{C}(12)$ & $-3421(4)$ & $-1840(2)$ & $3487(3)$ & $53(1)$ \\
$\mathrm{C}(13)$ & $-3223(4)$ & $-1030(2)$ & $3839(3)$ & $47(1)$ \\
$\mathrm{C}(14)$ & $-2125(3)$ & $-493(2)$ & $3459(2)$ & $36(1)$ \\
$\mathrm{C}(15)$ & $-1930(3)$ & $380(2)$ & $3839(2)$ & $37(1)$ \\
$\mathrm{C}(16)$ & $-3192(4)$ & $858(2)$ & $4095(3)$ & $48(1)$ \\
$\mathrm{C}(17)$ & $-3015(5)$ & $1644(2)$ & $4514(3)$ & $55(1)$ \\
$\mathrm{C}(18)$ & $-1582(5)$ & $1973(2)$ & $4668(3)$ & $55(1)$ \\
$\mathrm{C}(19)$ & $-317(4)$ & $1528(2)$ & $4391(2)$ & $47(1)$ \\
$\mathrm{C}(20)$ & $-465(4)$ & $728(2)$ & $3968(2)$ & $38(1)$ \\
$\mathrm{C}(21)$ & $932(4)$ & $202(2)$ & $3792(2)$ & $37(1)$ \\
\hline & & & & \\
\hline
\end{tabular}

Table 5. Bond lengths (in Angstroms) with standard deviations for complex 11

$\begin{array}{ll}\mathrm{Ni}(1)-\mathrm{N}(1) & 1.997(2) \\ \mathrm{Ni}(1)-\mathrm{N}(2) & 2.047(2) \\ \mathrm{Ni}(1)-\mathrm{C}(1) & 2.2229(11) \\ \mathrm{Ni}(1)-\mathrm{C}(2) & 2.2447(10) \\ \mathrm{N}(1)-\mathrm{C}(\mathrm{S}) & 1.342(4) \\ \mathrm{N}(1)-\mathrm{C}(1) & 1.344(4) \\ \mathrm{C}(1)-\mathrm{C}(2) & 1.372(5) \\ \mathrm{C}(2)-\mathrm{C}(3) & 1.368(5)\end{array}$




$\begin{array}{ll}\mathrm{N}(2)-\mathrm{C}(7) & 1.501(4) \\ \mathrm{N}(2)-\mathrm{C}(8) & 1.505(4) \\ \mathrm{N}(2)-\mathrm{C}(21) & 1.506(4) \\ \mathrm{C}(3)-\mathrm{C}(4) & 1.368(5) \\ \mathrm{C}(4)-\mathrm{C}(5) & 1.397(4) \\ \mathrm{C}(5)-\mathrm{C}(6) & 1.495(5) \\ \mathrm{C}(6)-\mathrm{C}(7) & 1.525(5) \\ \mathrm{C}(8)-\mathrm{C}(9) & 1.506(4) \\ \mathrm{C}(9)-\mathrm{C}(10) & 1.393(4) \\ \mathrm{C}(9)-\mathrm{C}(14) & 1.401(4) \\ \mathrm{C}(10)-\mathrm{C}(11) & 1.386(5) \\ \mathrm{C}(11)-\mathrm{C}(12) & 1.377(5) \\ \mathrm{C}(12)-\mathrm{C}(13) & 1.381(5) \\ \mathrm{C}(13)-\mathrm{C}(14) & 1.399(4) \\ \mathrm{C}(14)-\mathrm{C}(15) & 1.487(4) \\ \mathrm{C}(15)-\mathrm{C}(16) & 1.395(4) \\ \mathrm{C}(15)-\mathrm{C}(20) & 1.403(4) \\ \mathrm{C}(16)-\mathrm{C}(17) & 1.380(5) \\ \mathrm{C}(17)-\mathrm{C}(18) & 1.370(6) \\ \mathrm{C}(18)-\mathrm{C}(19) & 1.379(5) \\ \mathrm{C}(19)-\mathrm{C}(20) & 1.400(5) \\ \mathrm{C}(20)-\mathrm{C}(21) & 1.508(4)\end{array}$

Table 6. Bond angles [deg] for complex 11

$\begin{array}{ll}\mathrm{N}(1)-\mathrm{Ni}(1)-\mathrm{N}(2) & 99.87(10) \\ \mathrm{N}(1)-\mathrm{Ni}(1)-\mathrm{C} 1(1) & 100.49(8) \\ \mathrm{N}(2)-\mathrm{Ni}(1)-\mathrm{C} 1(1) & 110.81(7) \\ \mathrm{N}(1)-\mathrm{Ni}(1)-\mathrm{C} 1(2) & 102.97(8) \\ \mathrm{N}(2)-\mathrm{Ni}(1)-\mathrm{C} 1(2) & 107.03(7) \\ \mathrm{C} 1(1)-\mathrm{Ni}(1)-\mathrm{Cl}(2) & 130.68(4) \\ \mathrm{C}(5)-\mathrm{N}(1)-\mathrm{C}(1) & 119.2(3) \\ \mathrm{C}(5)-\mathrm{N}(1)-\mathrm{Ni}(1) & 123.7(2) \\ \mathrm{C}(1)-\mathrm{N}(1)-\mathrm{Ni}(1) & 116.8(2) \\ \mathrm{N}(1)-\mathrm{C}(1)-\mathrm{C}(2) & 122.5(3) \\ \mathrm{C}(3)-\mathrm{C}(2)-\mathrm{C}(1) & 118.9(4) \\ \mathrm{C}(7)-\mathrm{N}(2)-\mathrm{C}(8) & 111.1(2) \\ \mathrm{C}(7)-\mathrm{N}(2)-\mathrm{C}(21) & 106.4(2) \\ \mathrm{C}(8)-\mathrm{N}(2)-\mathrm{C}(21) & 108.8(2) \\ \mathrm{C}(7)-\mathrm{N}(2)-\mathrm{Ni}(1) & 109.6(2) \\ \mathrm{C}(8)-\mathrm{N}(2)-\mathrm{Ni}(1) & 109.2(2)\end{array}$




$\begin{array}{ll}\mathrm{C}(21)-\mathrm{N}(2)-\mathrm{Ni}(1) & 111.8(2) \\ \mathrm{C}(4)-\mathrm{C}(3)-\mathrm{C}(2) & 119.2(3) \\ \mathrm{C}(3)-\mathrm{C}(4)-\mathrm{C}(5) & 120.0(3) \\ \mathrm{N}(1)-\mathrm{C}(5)-\mathrm{C}(4) & 120.1(3) \\ \mathrm{N}(1)-\mathrm{C}(5)-\mathrm{C}(6) & 118.3(3) \\ \mathrm{C}(4)-\mathrm{C}(5)-\mathrm{C}(6) & 121.6(3) \\ \mathrm{C}(\mathrm{S})-\mathrm{C}(6)-\mathrm{C}(7) & 115.1(3) \\ \mathrm{N}(2)-\mathrm{C}(7)-\mathrm{C}(6) & 114.6(3) \\ \mathrm{N}(2)-\mathrm{C}(8)-\mathrm{C}(9) & 116.3(2) \\ \mathrm{C}(10)-\mathrm{C}(9)-\mathrm{C}(14) & 119.7(3) \\ \mathrm{C}(10)-\mathrm{C}(9)-\mathrm{C}(8) & 120.6(3) \\ \mathrm{C}(14)-\mathrm{C}(9)-\mathrm{C}(8) & 119.2(3) \\ \mathrm{C}(11)-\mathrm{C}(10)-\mathrm{C}(9) & 120.3(3) \\ \mathrm{C}(12)-\mathrm{C}(11)-\mathrm{C}(10) & 120.3(3) \\ \mathrm{C}(11)-\mathrm{C}(12)-\mathrm{C}(13) & 120.0(3) \\ \mathrm{C}(12)-\mathrm{C}(13)-\mathrm{C}(14) & 120.9(3) \\ \mathrm{C}(13)-\mathrm{C}(14)-\mathrm{C}(9) & 118.8(3) \\ \mathrm{C}(13)-\mathrm{C}(14)-\mathrm{C}(15) & 120.4(3) \\ \mathrm{C}(9)-\mathrm{C}(14)-\mathrm{C}(15) & 120.8(3) \\ \mathrm{C}(16)-\mathrm{C}(15)-\mathrm{C}(20) & 119.0(3) \\ \mathrm{C}(16)-\mathrm{C}(15)-\mathrm{C}(14) & 120.7(3) \\ \mathrm{C}(20)-\mathrm{C}(15)-\mathrm{C}(14) & 120.2(3) \\ \mathrm{C}(17)-\mathrm{C}(16)-\mathrm{C}(15) & 121.1(4) \\ \mathrm{C}(18)-\mathrm{C}(17)-\mathrm{C}(16) & 119.9(4) \\ \mathrm{C}(17)-\mathrm{C}(18)-\mathrm{C}(19) & 120.3(4) \\ \mathrm{C}(18)-\mathrm{C}(19)-\mathrm{C}(20) & 120.9(3) \\ \mathrm{C}(19)-\mathrm{C}(20)-\mathrm{C}(15) & 118.7(3) \\ \mathrm{C}(19)-\mathrm{C}(20)-\mathrm{C}(21) & 120.2(3) \\ \mathrm{C}(15)-\mathrm{C}(20)-\mathrm{C}(21) & 120.6(3) \\ \mathrm{N}(2)-\mathrm{C}(21)-\mathrm{C}(20) & 115.6(2) \\ & \end{array}$

\section{Experimental Section}

General Procedures. Infrared spectra were recorded on a Perkin Elmer 2000 spectrophotometer using potassium bromide discs (4000-400 $\mathrm{cm}^{-1}$ ), hexachlorobutadiene mulls (HCBD; 40002000 and $\left.1500-1250 \mathrm{~cm}^{-1}\right)$, polyethylene discs $\left(500-30 \mathrm{~cm}^{-1}\right)$ or nujol mulls $\left(500-30 \mathrm{~cm}^{-1}\right)$. Infrared spectra were recorded on a Perkin Elmer 2000 spectrophotometer using potassium bromide discs (4000-400 cm and nujol mulls $\left(650-30 \mathrm{~cm}^{-1}\right)$ NMR spectra were recorded on a Bruker AMX 400 spectrometer and chemical shifts are reported relative to the solvent peaks. 
Low resolution mass spectra were obtained on a Hewlett-Packard 5988A mass spectrometer, and high resolution analyses on a Kratos MS8ORF double focussing magnetic sector instrument (Cape Technikon Mass spectrometry unit). Microanalysis (combustion analysis) was conducted at the University of Cape Town, and the data for the zinc complexes are reported in Table 1. Melting points were obtained using a Kofler hot-stage microscope and are uncorrected.

\section{N-[(2-Benzimidazolyl)ethyl]benzamide (1a)}

Benzoic acid (1.00 g, $8.19 \mathrm{mmol})$ was dissolved in dry DMF $(10 \mathrm{~mL})$ in a round- bottomed flask fitted with a reflux condenser and drying tube. The solution was warmed to $40^{\circ} \mathrm{C}$, and CDI $(2.16$ $\mathrm{g}, 13.32 \mathrm{mmol}$ ) was added with stirring. The mixture was stirred for $5 \mathrm{~min}$ at $40^{\circ} \mathrm{C}$, after which time, gas evolution ceased. After cooling to room temperature, 2-(2-aminoethyl)benzimidazole (1.32 g, $8.19 \mathrm{mmol}$ ) was added. The resulting solution was stirred for $60 \mathrm{~h}$ at room temperature, and the reaction was quenched with $\mathrm{H}_{2} \mathrm{O}(7 \mathrm{~mL})$. The pale pink powder that precipitated was filtered off and washed with aqueous $\mathrm{Na}_{2} \mathrm{CO}_{3}(1 \mathrm{M} ; 50 \mathrm{~mL})$ to give $N$-[(2-benzimidazolyl)ethyl]benzamide $1 \mathrm{a}\left(1.58 \mathrm{~g}, 73 \%\right.$ ), $\mathrm{mp}>250^{\circ} \mathrm{C}^{25}$ (from DMF-H $\mathrm{H}_{2} \mathrm{O}$ (Found: $\mathbf{M H}^{+}$266.1294. $\mathrm{C}_{16} \mathrm{H}_{15} \mathrm{~N}_{3} \mathrm{O}$ requires, $M H$ 266.1293); $v_{\max }\left(\mathrm{KBr} / \mathrm{cm}^{-1}, 3305\right.$ (amide $\mathrm{NH}$ ), 3176 (benzimidazole $\left.\mathrm{NH}\right), 1638$ (CO); $\delta_{\mathrm{H}}(400 \mathrm{MHz}$; DMSO-d $) 3.09\left(2 \mathrm{H}, \mathrm{t}, \mathrm{NHCH}_{2} \mathrm{CH}_{2}\right), 3.73\left(2 \mathrm{H}, \mathrm{m}, \mathrm{NHCH}_{2} \mathrm{CH}_{2}\right), 7.12(2 \mathrm{H}$, $\mathrm{m}, \mathrm{ArH}), 7.49$ (5H, m, ArH), 7.84(2H, d, ArH), $8.63(1 \mathrm{H}, \mathrm{m}$, amide NH), $12.50(1 \mathrm{H}, \mathrm{s}, \mathrm{NH})$; $\delta_{\mathrm{c}}\left(100 \mathrm{MHz} ; \mathrm{DMSO}-d_{6}\right) 28.8$ ( $\left.\mathrm{t}, \mathrm{NHCH}_{2} \mathrm{CH}_{2}\right), 38.0$ (t, $\left.\mathrm{NHCH}_{2} \mathrm{CH}_{2}\right), 110.8(\mathrm{~d}), 118.1(\mathrm{~d})$, 120.8(d), 121.5(d), 127.1(d), 128.2(d), 131.1(d), 134.2(s), 134.4(s), 143.2(s) and 152.8(s) (ArC) and $166.2(\mathrm{~s}, \mathrm{CO})$.

\section{$\mathrm{N}$-[(2-Imidazolyl)ethyl]benzamide (1b)}

Benzoic acid $(1.00 \mathrm{~g}, 8.19 \mathrm{mmol})$ was dissolved in dry DMF $(10 \mathrm{~mL})$ in a round-bottomed flask fitted with a reflux condenser and drying tube. The solution was warmed to $40^{\circ} \mathrm{C}$, and CDI $(2.16$ g, $13.32 \mathrm{mmol}$ ) was added with stirring. The mixture was stirred for $5 \mathrm{~min}$ at $40^{\circ} \mathrm{C}$, after which time, gas evolution ceased. After cooling to room temperature, histamine (0.92 g, $8.19 \mathrm{mmol})$ was added. The resulting solution was stirred for $46 \mathrm{~h}$ at room temperature, and the reaction was quenched with $\mathrm{H}_{2} \mathrm{O}(7 \mathrm{~mL})$. Volatiles were removed under reduced pressure and aqueous $1 \mathrm{M}$ $\mathrm{Na}_{2} \mathrm{CO}_{3}(50 \mathrm{~mL})$ was added. The mixture was extracted with EtOAc $(4 \mathrm{x} 100 \mathrm{~mL})$, and the combined extracts were washed with $\mathrm{H}_{2} \mathrm{O}(100 \mathrm{~mL})$ and brine $(100 \mathrm{~mL})$, and dried $\left(\mathrm{MgSO}_{4}\right)$. The solvent was evaporated to afford, as a yellow solid, $N$-[(2-imidazolyl)ethyl]benzamide 1b

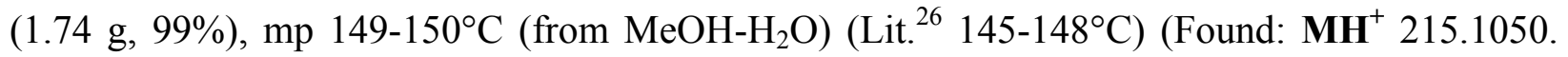
$\mathrm{C}_{16} \mathrm{H}_{15} \mathrm{~N}_{3} \mathrm{O}$ requires, $M H$ 215.1059); $v_{\max }\left(\mathrm{KBr} / \mathrm{cm}^{-1}\right.$ ) 3223 (amide $\mathrm{NH}$ ), 3152 (imidazole $\mathrm{NH}$ ) and $1634(\mathrm{CO}) ; \delta_{\mathrm{H}}\left(400 \mathrm{MHz} ; \mathrm{DMSO}-d_{6}\right) 2.77\left(2 \mathrm{H}, \mathrm{t}, \mathrm{NHCH}_{2} \mathrm{CH}_{2}\right), 3.45-3.53(2 \mathrm{H}, \mathrm{m}$, $\left.\mathrm{NHCH}_{2} \mathrm{CH}_{2}\right), 6.82(1 \mathrm{H}, \mathrm{s}, \mathrm{ArH}), 7.45(2 \mathrm{H}, \mathrm{t}, \mathrm{ArH}), 7.48-7.55(2 \mathrm{H}, \mathrm{m}, \mathrm{ArH}), 7.83$ (2H, d, ArH), $8.53(1 \mathrm{H}, \mathrm{m}$, amide $\mathrm{NH}), 11.82(1 \mathrm{~N}, \mathrm{~s}, \mathrm{NH})$.

\section{$\mathrm{N}$-[(2-Pyridinyl)ethyl]benzamide (1c)}

Following the procedure used for the preparation of $N$-[(2-benzimidazolyl)ethyl]-benzamide 1a, benzoic acid (1.00 g, $8.19 \mathrm{mmol})$, CDI (2.16 g, $13.32 \mathrm{mmol})$ and 2-(2-aminoethyl)pyridine (0.98 $\mathrm{mL}, 8.19 \mathrm{mmol})$ in dry DMF $(10 \mathrm{~mL})$ was stirred for $72 \mathrm{~h}$ at room temperature before quenching 
with $\mathrm{H}_{2} \mathrm{O}(7 \mathrm{~mL})$. Volatiles were removed under reduced pressure, and aqueous $1 \mathrm{M} \mathrm{Na}_{2} \mathrm{CO}_{3}(50$ $\mathrm{mL})$ was added to the residual oil. The mixture was extracted with EtOAc $(4 \mathrm{x} 100 \mathrm{~mL})$, and the combined extracts were washed with $\mathrm{H}_{2} \mathrm{O}(100 \mathrm{~mL})$ and brine $(100 \mathrm{~mL})$, and dried $\left(\mathrm{MgSO}_{4}\right)$. The solvent was evaporated and the residue chromatographed [chromatography on silica gel; elution with $\left.\mathrm{CHCI}_{3}(1: 3: 3)\right]$ to afford, as a white crystalline solid, $N$-[(2pyridinyl)ethyl]benzamide $1 \mathrm{c}(1.61 \mathrm{~g}, 87 \%)$, mp $68-69^{\circ} \mathrm{C}$ (Lit. $\left.{ }^{27} 68-70^{\circ} \mathrm{C}\right)$ (Found: $\mathbf{M}^{+} 226.1097$. $\mathrm{C}_{28} \mathrm{H}_{26} \mathrm{O}_{2} \mathrm{~N}_{4}$ requires, $M$ 226.1107); $v_{\max }\left(\mathrm{KBr} / \mathrm{cm}^{-1}\right) 3290$ (amide $\mathrm{NH}$ ) and $1627(\mathrm{CO}) ; \delta_{\mathrm{H}}(400$ MHz; DMSO-d $d_{6} 3.01\left(2 \mathrm{H}, \mathrm{t}, \mathrm{NHCH}_{2} \mathrm{CH}_{2}\right), 3.59-3.67\left(2 \mathrm{H}, \mathrm{m}, \mathrm{NHCH}_{2} \mathrm{CH}_{2}\right), 6.85-7.23(2 \mathrm{H}, \mathrm{m}$, $\operatorname{ArH}), 7.27$ (2H, d, ArH), 7.41 -7.47 (4H, m, ArH), 7.48-7.52 (2H, m, ArH), 7.67-7.72 (2H, m, $\operatorname{ArH})$, 7.79-7.85 (4H, m, ArH), 8.49-8.52 (2H, m, ArH), 8.53 (1 H, m, amide NH); $\delta_{\mathrm{c}}(100 \mathrm{MHz}$; DMSO-d $d_{6} 37.2$ (t, $\left.\mathrm{NHCH}_{2} \mathrm{CH}_{2}\right), 39.1$ (t, $\left.\mathrm{NHCH}_{2} \mathrm{CH}_{2}\right), 121.4(\mathrm{~d}), 123.0(\mathrm{~d}), 127.0(\mathrm{~d}), 128.1(\mathrm{~d})$, 130.9(d), 134.5(s), 136.3(d), 149.0(d), 159.3(s) (ArC) and 166.0 (s, CO).

\section{The manganese complex $3 a$}

A hot solution of $N$-[(2-benzimidazolyl)ethyl]benzamide 1a $(0.15 \mathrm{~g}, 0.57 \mathrm{mmol})$ in DMF (13 $\mathrm{mL}$ ) was added dropwise to a solution of $\mathrm{MnCl}_{2} .4 \mathrm{H}_{2} \mathrm{O}(0.11 \mathrm{~g}, 0.57 \mathrm{mmol})$ in DMF $(2 \mathrm{~mL})$, and the reaction mixture was stirred for $60 \mathrm{~h}$. The solvent was evaporated off under reduced pressure, re-dissolved in $\mathrm{DMF}$, and $\mathrm{Et}_{2} \mathrm{O}$ and hexane added to precipitate, as a light-brown solid, the manganese complex 3a $(0.14 \mathrm{~g}, 57 \%), \mathrm{mp} 189-192^{\circ} \mathrm{C} ; v_{\max }\left(\mathrm{KBr} / \mathrm{cm}^{-1}\right) 3321$ (amide $\left.\mathrm{NH}\right), 3200$ (benzimidazole $\mathrm{NH}$ ) and $1639(\mathrm{CO}) ; v_{\max }\left(\right.$ nujol $\left./ \mathrm{cm}^{-1}\right) 278(\mathrm{Mn}-\mathrm{Cl})$.

\section{The manganese complex $3 \mathrm{c}$}

To a stirred solution of $N$-[(2-pyridinyl)ethyl]benzamide $1 \mathrm{c}(0.17 \mathrm{~g}, 0.75 \mathrm{mmol})$ in $\mathrm{MeOH}$ (3 $\mathrm{mL})$, a solution of $\mathrm{MnCl}_{2} .4 \mathrm{H}_{2} \mathrm{O}(0.17 \mathrm{~g}, 0.75 \mathrm{mmol})$ in $\mathrm{MeOH}(5 \mathrm{~mL})$ was added and the reaction mixture stirred for $53 \mathrm{~h}$. The solvent was removed under reduced pressure to less than half the original volume before adding $\mathrm{Et}_{2} \mathrm{O}$ to precipitate the product. The residual oil that precipitated was washed with $\mathrm{Et}_{2} \mathrm{O}$ followed by drying under vacuum to afford, as a light-brown powder, the manganese complex 3c, $(0.29 \mathrm{~g}, 97 \%), \mathrm{mp} 103-105^{\circ} \mathrm{C} ; v_{\max }\left(\mathrm{KBr} / \mathrm{cm}^{-1}\right) 3344$ (amide $\mathrm{NH})$ and $1623(\mathrm{CO}) ; v_{\max }\left(\right.$ nujol $\left./ \mathrm{cm}^{-1}\right) 276(\mathrm{Mn}-\mathrm{Cl})$.

\section{The manganese complex 4}

A solution of 2,2'-bis $\{[2-(4-i m i d a z o l y l) e t h y l a m i n o]$ carbonyl $\}$ biphenyl $\mathbf{2 b}(0.20 \mathrm{~g}, 0.46 \mathrm{mmol})$ in $\mathrm{MeOH}(9 \mathrm{~mL})$ was added to a stirred solution of $\mathrm{MnCl}_{2} .4 \mathrm{H}_{2} \mathrm{O}(0.18 \mathrm{~g}, 0.92 \mathrm{mmol})$ in $\mathrm{MeOH}(3$ $\mathrm{mL}$ ). After stirring for $39 \mathrm{~h}, \mathrm{Et}_{2} \mathrm{O}$ was added to precipitate the product. The manganese complex 4 was obtained as a cream powder after recrystallising from $\mathrm{MeOH}_{-} \mathrm{Et}_{2} \mathrm{O}(0.20 \mathrm{~g}, 72 \%), \mathrm{mp} 205-$ $207^{\circ} \mathrm{C} ; v_{\max }\left(\mathrm{KBr} / \mathrm{cm}^{-1}\right) 3237$ (amide $\left.\mathrm{NH}\right), 3137$ (imidazole $\left.\mathrm{NH}\right)$ and $1630(\mathrm{CO}) ; v_{\max }\left(\mathrm{nujol} / \mathrm{cm}^{-1}\right)$ 271 and $217(\mathrm{Mn}-\mathrm{Cl})$.

\section{The nickel complex 5}

A solution of 2,2'-bis $\{[2-(2-p y r i d y l) e t h y l a m i n o]$ carbonyl $\}$ biphenyl $2 \mathrm{c}(0.20 \mathrm{~g}, 0.44 \mathrm{mmol})$ in $\mathrm{MeOH}(5 \mathrm{~mL})$ was added to a stirred solution of $\mathrm{NiCl}_{2} .6 \mathrm{H}_{2} \mathrm{O}(0.22 \mathrm{~g}, 0.92 \mathrm{mmol})$ in $\mathrm{MeCN}(5$ $\mathrm{mL}$ ). After stirring for $2.5 \mathrm{~d}, \mathrm{Et}_{2} \mathrm{O}$ was added to precipitate, as a light-green, hygroscopic solid, the nickel complex $5(0.26 \mathrm{~g}, 72 \%)$, mp $48-49^{\circ} \mathrm{C}$; $\mathrm{v}_{\max }\left(\mathrm{KBr} / \mathrm{cm}^{-1}\right) 3336($ amide $\mathrm{NH})$ and $1619(\mathrm{CO}) ; \mathrm{v}_{\max }\left(\right.$ nujol $\left./ \mathrm{cm}^{-1}\right) 325$ and $276(\mathrm{Ni}-\mathrm{Cl})$. 


\section{The nickel complex 6}

A hot solution of 2,2'-bis $\{[2-(2-$ benzimidazolyl)ethylamino]carbonyl $\}$ biphenyl 2a $(0.23 \mathrm{~g}, 0.44$ mmol) was added dropwise to a stirred solution of $\mathrm{NiCl}_{2} .6 \mathrm{H}_{2} \mathrm{O}(0.22 \mathrm{~g}, 0.92 \mathrm{mmol})$ in DMF (7 $\mathrm{mL}$ ). The reaction mixture was stirred for $57 \mathrm{~h}$ before $\mathrm{Et}_{2} \mathrm{O}$ was added to precipitate, as a lightgreen solid, the nickel complex $6(0.29 \mathrm{~g}, 53 \%), \mathrm{mp}>250^{\circ} \mathrm{C} ; \mathrm{v}_{\max }\left(\mathrm{KBr} / \mathrm{cm}^{-1}\right) 3183$ (amide $\left.\mathrm{NH}\right)$ and $1650(\mathrm{CO}) ; \mathrm{v}_{\max }\left(\right.$ nujol $\left./ \mathrm{cm}^{-1}\right) 387(\mathrm{Ni}-\mathrm{Cl})$.

\section{The nickel complex 7}

A solution of 2,2'-bis $\{[2-(4-i m i d a z o l y l) e t h y l a m i n o]$ carbonyl $\}$ biphenyl $\mathbf{2 b}(0.15 \mathrm{~g}, 0.35 \mathrm{mmol})$ in DMF $(10 \mathrm{~mL})$ was added dropwise to a stirred solution of $\mathrm{NiCl}_{2} \cdot 6 \mathrm{H}_{2} \mathrm{O}(0.17 \mathrm{~g}, 0.72 \mathrm{mmol})$ in $\mathrm{MeOH}(5 \mathrm{~mL})$. Stirring was continued for $55 \mathrm{~h}$ before adding $\mathrm{Et}_{2} \mathrm{O}$ to precipitate, as a hygroscopic dark blue-green solid, the nickel complex 7, (0.10 g, 27\%), mp 204-205 ${ }^{\circ}$; $\mathrm{v}_{\max }\left(\mathrm{KBr} / \mathrm{cm}^{-1}\right) 3248$ (amide $\left.\mathrm{NH}\right), 3143$ (imidazole $\mathrm{NH}$ ) and $1653(\mathrm{CO}) ; \mathrm{v}_{\max }\left(\right.$ nujol/ $/ \mathrm{cm}^{-1}$ ) 378 (Ni-Cl).

\section{The nickel complex 11}

To a stirred solution of $\mathrm{NiCl}_{2} \cdot 6 \mathrm{H}_{2} \mathrm{O}(0.22 \mathrm{~g}, 0.92 \mathrm{mmol})$ in $\mathrm{MeOH}(4 \mathrm{~mL})$, a solution of 1-[2-(2pyridyl)ethyl]dibenz[c,e]perhydroazepine $\mathbf{1 0}^{28}(0.19 \mathrm{~g}, 0.44 \mathrm{mmol})$ in $\mathrm{MeCN}(10 \mathrm{~mL})$ was added dropwise, and stirring was continued for $19 \mathrm{~h}$. The solvent was allowed to evaporate off at room temperature, during which time, purple crystals precipitated from the reaction mixture and were filtered off to give the nickel complex $11(0.13 \mathrm{~g}, 65 \%), \mathrm{mp}>250^{\circ} \mathrm{C} ; \mathrm{v}_{\max }\left(\mathrm{nujol} / \mathrm{cm}^{-1}\right) 329$ and 289 (Ni-Cl).

\section{The zinc complex 8a}

A solution of N-[(2-benzimidazolyl)ethyl]benzamide 1a $(0.15 \mathrm{~g}, 0.57 \mathrm{mmol})$ in hot DMF (6 mL) was added dropwise to a solution of $\mathrm{ZnCl}_{2}(0.08 \mathrm{~g}, 0.57 \mathrm{mmol})$ in a mixture of $\mathrm{MeOH}(4 \mathrm{~mL})$ and DMF ( $4 \mathrm{~mL})$, and the reaction mixture was stirred for $48 \mathrm{~h}$. The solvent was evaporated off under reduced pressure, re-dissolved in $\mathrm{DMF}$, and $\mathrm{Et}_{2} \mathrm{O}$ and hexane added to precipitate, as a light-brown solid, the zinc complex $8 \mathbf{a}(0.23 \mathrm{~g}, 85 \%), \mathrm{mp}>96-98^{\circ} \mathrm{C} ; v_{\max }\left(\mathrm{KBr} / \mathrm{cm}^{-1}\right) 3321$ (amide $\mathrm{NH}), 3183$ (imidazole $\mathrm{NH}$ ) and $1646(\mathrm{CO}) ; v_{\max }\left(\right.$ nujol/ $\left.\mathrm{cm}^{-1}\right) 287(\mathrm{Zn}-\mathrm{Cl}) ; \delta_{\mathrm{H}}(400 \mathrm{MHz}$; DMSOd $) 3.23\left(2 \mathrm{H}, \mathrm{m}, \mathrm{CH}_{2}\right), 3.72\left(2 \mathrm{H}, \mathrm{m}, \mathrm{CH}_{2} \mathrm{~N}\right), 7.24(2 \mathrm{H}$, br s, ArH), $7.44(2 \mathrm{H}, \mathrm{t}, \mathrm{ArH}), 7.51(1 \mathrm{H}, \mathrm{t}$, $\operatorname{ArH}), 7.70\left(2 \mathrm{H}\right.$, br s, ArH), $7.82(2 \mathrm{H}, \mathrm{d}, \mathrm{ArH}), 7.95(1 \mathrm{H} \mathrm{s}, \mathrm{NH})$ and $13.10(1 \mathrm{H}, \mathrm{br} \mathrm{s}, \mathrm{NH}) ; \delta_{\mathrm{c}}(100$ MHz; DMSO-d $d_{6} 28.4$ (t, $\left.\mathrm{CH}_{2}\right), 38.8\left(\mathrm{t}, \mathrm{CH}_{2} \mathrm{~N}\right), 122.3$ (d), 127.1 (d), 128.1 (d), 131.0 (d), 134.3 (s), $154.3(\mathrm{~s})$ and $162.2(\mathrm{~d})(\mathrm{ArC})$ and $166.4(\mathrm{~s}, \mathrm{C}=\mathrm{O})$.

\section{The zinc complex 8c}

To a stirred solution of N-pyridinyl)ethyl]benzamide $1 \mathrm{c}(0.17 \mathrm{~g}, 0.75 \mathrm{mmol})$ in $\mathrm{MeOH}(3 \mathrm{~mL})$, a solution of $\mathrm{ZnCl}_{2}(0.17 \mathrm{~g}, 0.75 \mathrm{mmol})$ in $\mathrm{MeOH}(5 \mathrm{~mL})$ was added and the reaction mixture stirred for $53 \mathrm{~h}$. The solvent was removed under reduced pressure and the residue washed with $\mathrm{Et}_{2} \mathrm{O}$ to afford, as a yellow-white semi-solid, the zinc complex $8 \mathrm{c},(0.29 \mathrm{~g}, 97 \%) ; v_{\max }\left(\mathrm{KBr} / \mathrm{cm}^{-1}\right)$ 3496 (amide $\mathrm{NH})$ and $1627(\mathrm{CO}) ; v_{\max }\left(\right.$ nujol/ $\left.\mathrm{cm}^{-1}\right) 278(\mathrm{Zn}-\mathrm{Cl}) ; \delta_{\mathrm{H}}\left(400 \mathrm{MHz}\right.$; DMSO- $\left.d_{6}\right) 3.01$ $\left(2 \mathrm{H}, \mathrm{t}, \mathrm{CH}_{2}\right), 3.62\left(2 \mathrm{H}, \mathrm{q}, \mathrm{CH}_{2} \mathrm{~N}\right), 7.22(1 \mathrm{H}, \mathrm{t}, \mathrm{ArH}), 7.28(1 \mathrm{H}, \mathrm{d}, \mathrm{ArH}), 7.44(2 \mathrm{H}, \mathrm{t}, \mathrm{ArH}), 7.50$ $(1 \mathrm{H}, \mathrm{t}, \mathrm{ArH}), 7.70(1 \mathrm{H}, \mathrm{t}, \operatorname{ArH}), 7.80(2 \mathrm{H}, \mathrm{d}, \mathrm{ArH}), 8.51(1 \mathrm{H}, \mathrm{d}, \mathrm{ArH})$ and $8.56(1 \mathrm{H}, \mathrm{m}, \mathrm{NH})$; 
$\delta_{\mathrm{c}}\left(100 \mathrm{MHz}\right.$; DMSO- $\left.d_{6}\right) 37.2\left(\mathrm{t}, \mathrm{CH}_{2}\right), 39.2\left(\mathrm{t}, \mathrm{CH}_{2} \mathrm{~N}\right), 121.5$ (d), 123.1 (d), 127.0 (d), 128.2 (d), 131.0 (d), 134.5 (s), 136.5 (d), 149.0 (d) and 159.1 (s) (ArC) and 166.0 (s, C=O).

\section{The zinc complex 9a}

A hot, clear, colourless solution of 2,2'-bis $\{[2-(2-$ benzimidazolyl)ethylamino $]$ carbonyl $\}$-biphenyl 2a $(0.25 \mathrm{~g}, 0.47 \mathrm{mmol})$ in DMF $(40 \mathrm{~mL})$ was added to a stirred solution of $\mathrm{ZnCl}_{2}(0.13 \mathrm{~g}, 0.95$ $\mathrm{mmol})$ in DMF $(5 \mathrm{~mL})$ and $\mathrm{MeOH}(5 \mathrm{~mL})$. After stirring for $68 \mathrm{~h} \mathrm{Et}$ was added to precipitate the product. Recrystallisation from $\mathrm{DMF}_{-} \mathrm{Et}_{2} \mathrm{O}$ yielded, as a cream-white solid, the zinc complex 9a $(0.22 \mathrm{~g}, 62 \%), \mathrm{mp}>250^{\circ} \mathrm{C} ; v_{\max }\left(\mathrm{KBr} / \mathrm{cm}^{-1}\right) 3255$ (amide $\left.\mathrm{NH}\right), 3152$ (imidazole $\mathrm{NH}$ ) and 1648 (CO); $v_{\max }\left(\right.$ nujol $\left./ \mathrm{cm}^{-1}\right) 278(\mathrm{Zn}-\mathrm{Cl}) ; \delta_{\mathrm{H}}(400 \mathrm{MHz}$; DMSO-d $) 2.85\left(2 \mathrm{H}\right.$, br s, $\left.\mathrm{CH}_{2}\right), 3.40$ [2H, $\left.\mathrm{m}(\mathrm{sh}), \mathrm{CH}_{2} \mathrm{~N}\right], 6.96-8.69(9 \mathrm{H}$, series of br s, ArH and $\mathrm{NH})$ and $12.70\left(1 \mathrm{H}\right.$, br s, NH); $\delta_{\mathrm{c}}(100$ MHz; DMSO-d $628.0\left(\mathrm{t}, \mathrm{CH}_{2}\right.$ ), $37.2\left(\mathrm{t}, \mathrm{CH}_{2} \mathrm{~N}\right), 111.2$ (br s), 121.9 (br d), 127.2 (d), 128.9 (d), 129.1 (d), $135.6(\mathrm{~s}), 138.9(\mathrm{~s}), 153.6(\mathrm{~s})$ and $162.2(\mathrm{~s})(\mathrm{ArC})$ and $169.0(\mathrm{~s}, \mathrm{C}=\mathrm{O})$.

\section{The zinc complex 9b}

A solution of 2,2'-bis $\{[2-(4-i m i d a z o l y l)$ ethylamino]carbonyl $\}$ biphenyl $\mathbf{2 b}(0.24 \mathrm{~g}, 0.56 \mathrm{mmol})$ in $\mathrm{MeOH}(20 \mathrm{~mL})$ was added to a stirred solution of $\mathrm{ZnCl}_{2}(0.15 \mathrm{~g}, 1.1 \mathrm{mmol})$ in $\mathrm{MeOH}(6 \mathrm{~mL})$. After stirring for $48 \mathrm{~h}, \mathrm{Et}_{2} \mathrm{O}$ was added to precipitate the product. The zinc complex 6a was obtained as a cream-white powder after recrystallising from $\mathrm{MeOH}_{-} \mathrm{Et}_{2} \mathrm{O}(0.15 \mathrm{~g}, 45 \%), \mathrm{mp}$ $>219-221^{\circ} \mathrm{C} ; \quad v_{\max }\left(\mathrm{KBr} / \mathrm{cm}^{-1}\right) 3237$ (amide $\mathrm{NH}$ ), 3137 (imidazole $\mathrm{NH}$ ) and 1630 (CO); $v_{\max }\left(\right.$ nujol $\left./ \mathrm{cm}^{-1}\right) 281(\mathrm{Zn}-\mathrm{Cl}) ; \delta_{\mathrm{H}}\left(400 \mathrm{MHz}\right.$; DMSO- $\left.d_{6}\right)$ 1.8-3.9 $\left(4 \mathrm{H}\right.$, series of br s, $\left.\mathrm{CH}_{2} \mathrm{CH}_{2} \mathrm{~N}\right)$, $6.85(1 \mathrm{H}$, br s, ArH), $6.89(1 \mathrm{H}, \mathrm{d}, \mathrm{ArH}), 7.36(3 \mathrm{H}$, br s, ArH $), 7.97(1 \mathrm{H}$, br s, ArH $), 8.60(1 \mathrm{H}$, br $\mathrm{d}, \mathrm{ArH})$ and $12.8\left(1 \mathrm{H}\right.$, br d, NH); $\delta_{\mathrm{c}}\left(100 \mathrm{MHz}\right.$; DMSO- $\left.d_{6}\right) 25.3 / 25.7^{*}\left(\mathrm{t}, \mathrm{CH}_{2}\right), 36.7 / 37.6^{*}(\mathrm{t}$, $\left.\mathrm{CH}_{2} \mathrm{~N}\right), 114.0,123.4,127.4,128.3,128.9 / 129.2$ and 136.3 (6 x d, ArC), 134.5, 139.0 and 139.4 ( 3 x s, ArC) and $168.4 / 169.2 *(\mathrm{~s}, \mathrm{C}=\mathrm{O})$.

X-Ray crystal data for complex 11. $\mathrm{C}_{21} \mathrm{H}_{20} \mathrm{Cl}_{2} \mathrm{~N}_{2} \mathrm{Ni}, M=430$; monoclinic, space group $\mathrm{P} 2(1) / \mathrm{n}$; $a=8.7689$ (5), $b=15.8377$ (9), $c=13.7979$ (8) $\AA, \alpha=90.00^{\circ} ; \beta=91.8760^{\circ}(10) ; \gamma=90.00^{\circ}, V$ $=1915.2(2) \AA^{3}, \mathrm{Z}=4, \mathrm{~F}(000)=888, \mathrm{D}_{\mathrm{c}}=1.491 \mathrm{gcm}^{-3}, \mu=1.299 \mathrm{~mm}^{-1}$. Data collection with graphite-monochromated Mo- $\mathrm{K}_{\alpha}$ radiation, $\lambda=0.71073 \Delta, T=296(2) \mathrm{K}, \theta$ range 1.96 to $28.28 \mathrm{E}$, 11748 reflections collected $(-11<\mathrm{h}<10,-20<\mathrm{k}<20,-17<1<16), 4317$ unique with $I>$ $2 \sigma(I)$. Hydrogen atoms were placed in calculated positions and the structure was solved by direct methods using SHELX-97; ${ }^{29}$ full-matrix least-squares refinement converged at $R_{1}=0.0494, w R_{2}$ $=0.0979, \mathrm{GOF}=1.132$. CCDC 704606 contains the supplementary crystallographic data for this paper. These data can be obtained free of charge from The Cambridge Crystallographic Data Centre via www.ccdc.cam.ac.uk/data_request/cif

\section{Catalytic studies}

The substrates 3,5-DTBP (100 eq.) and 3,5-DTBC (100 eq.) were added to solutions of the $\mathrm{Mn}(\mathrm{II})$ complexes $\left(0.01 \mathrm{~g}\right.$ ) in DMF (2 mL for 3a, 4; $2.5 \mathrm{~mL}$ for $\mathbf{3 c}$ ), typically containing $\mathrm{Et}_{3} \mathrm{~N}$ (see Table 3), to give substrate:complex molar ratios of 100:1. The resulting mixtures were aerated by stirring vigorously for $24 \mathrm{~h}$. At the conclusion of each reaction period, the mixture was concentrated to dryness in vacuo and the residue analysed by ${ }^{1} \mathrm{H}$ NMR spectroscopy to determine 
the substrate:product ratio. After analysis of the residue, diethyl ether was added to dissolve and remove 3,5-DTBC and 3,5-DTBQ from the complex. Recyclability was established by adding fresh substrate, $\mathrm{DMF}$ and $\mathrm{Et}_{3} \mathrm{~N}$ to the complex from the initial reaction, and stirring for $24 \mathrm{~h}$. The solvent was evaporated in vacuo and the residual material analyzed as before.

\section{Acknowledgements}

We are grateful to NRF, MINTEK and Rhodes University for generous financial support and Ms Leanne Cook (University of the Witwatersrand) for X-ray structure analysis.

\section{References}

1. Magnus, K. A.; Ton-That, H; Carpenter, J. E. Chem. Rev. 1994, 94, 727.

2. Karlin, K. D.; Gultneh,Y. J. Chem. Ed. 1985, 62, 983.

3. Solomon,E. I.; Sundaram, U. M.; Machonkin, T. E. Chem. Rev. 1996, 96, 2563.

4. Wellington, K. W. PhD Thesis, Rhodes University, 1999.

5. Kaye, P. T.; Nyokong, T.; Watkins, G. M.; Wellington, K. W. ARKIVOC 2002, (ix), 9.

6. Dismukes, G. C. Chem. Rev. 1996, 96, 2909.

7. Kim, E. E.; Wyckoff, H. W. J. Mol. Bio. 1991, $218,449$.

8. Christianson, O. W.; Lipscomb, W. N. Acc. Chem. Res. 1989, 22, 62.

9. Lipscomb, W. N.; Strater, N. Chem. Rev. 1996, 96, 2375.

10. Wilcox, D. E. Chem. Rev. 1996, 96, 2435.

11. (a) Sumner, J. B. J. Biol. Chem. 1926, 69, 435. (b) Volkmer, D.; Hörstman, A.; Griesar, K.; Haase, B.; Krebbs, B. Inorg. Chem. 1996, 35, 1132.

12. Fenton, D. E. In Biocoordination Chemistry, Oxford University Press: New York, 1995, p 29.

13. Burton, S. G.; Kaye, P. T.; Wellington, K. W. Synth. Commun. 2000, 30, 511.

14. Kaye, P. T.; Wellington, K. W. Synth. Commun. 2001, 31, 1.

15. Kaye, P. T.; Wellington, K. W. Synth. Commun. 2001, 31, 2405.

16. Burton, S. G. Ph.D Thesis, Rhodes University, 1993.

17. Thornton, D. A. J. Coord. Chem. 1991, 24, 142.

18. See, for example, Herr, H.; Spahl, W.; Trojandt, G.; Steglich, W.; Thaler, F.; van Eldik, R. Bioorganic \& Medicinal Chemistry 1999, 7, 699. Pesavento, R. P.; Pratt, D. A..; Jeffers, J.; van der Donk, W. A. J. Chem. Soc., Dalton Trans. 2006, 3326.

19. Vigato, P. A.; Tamburini, S.; Fenton, D. E. Coord. Chem. Rev. 1990, 106, 25.

20. Chyn, J. P.; Urbach, F. L. Inorg. Chim. Acta 1991, 189, 157.

21. Oishi, N.; Nishida,Y.; Ida, K.; Kida, S. Bull. Chem. Soc. Japan 1980, 53, 2847.

22. Kaye, P. T.; Watkins, G. M.; Wellington, K. W. S. Afr. J. Chem. 2005, 58, 1. 
23. Triller, M. U.; Pursche, D.; Hsieh, W. Y.; Pecoraro, V. L.; Rompel, A.; Krebs, B. Inorg. Chem. 2003, 42(20), 6274.

24. Kovala-Demertzi, D.; Hadjikakou, S. K.; Demertzis, M. A.; Deligiannakis, Y. J. Inorg. Biochem. 1998, 69, 223.

25. Reported as the hydrochloride salt by Nandi, M. M.; Ray, R. Indian Journal of Chemistry, Section B: Organic Chemistry Including Medicinal Chemistry 1986, 25B(2), 222; Chem. Abstr. 1987, 106, 138323.

26. Kaptein, B.; Barf, G.; Kellogg, R. M.; Van Bolhuis, F. J. Org. Chem. 1990 55, 1890.

27. Hankovszky, H. O.; Hideg, K. J. Med. Chem., 1966, 9, 151; Chem. Abstr. 1966, 64, 35747.

28. Burton, S. G.; Kaye, P. T.; Wellington, K. W. Synth. Commun. 2000, 30, 511.

29. Sheldrick, G. M. SHELX97, Program for the Refinement of Crystal Structures, University of Gottingen, Germany. 